\title{
Prediksi Curah Hujan Di Kota Pontianak Menggunakan Parameter Cuaca Sebagai Prediktor Pada Skala Bulanan, Dasarian Dan Harian
}

Asri Rachmawati ${ }^{1 *}$

\author{
1)Stasiun Meteorologi Supadio Pontianak \\ Badan Meteorologi Klimatologi Dan Geofisika \\ ${ }^{1 *}$ email : asriprada@gmail.com
}

\begin{abstract}
Abstrak
Telah dilakukan penelitian dengan metode jaringan syaraf tiruan propagasi balik untuk memprediksi curah hujan di Kota Pontianak dengan menggunakan parameter cuaca yakni suhu udara, kelembaban udara, tekanan udara dan penguapan sebagai parameter prediktor. Data yang digunakan adalah data pada periode 2005-2012 sebagai data latih dan 2013-2014 sebagai data uji. Keseluruhan proses dilakukan secara terpisah pada tiga bagian untuk skala waktu yang berbeda, yakni skala waktu bulanan, dasarian dan harian. Hasil model menunjukkan bahwa semakin besar skala waktu yang diteliti maka semakin tinggi ketepatan prediksi yang dihasilkan oleh model yang telah dibangun. Terlihat pada skala waktu bulanan, dasarian dan harian nilai koefisien korelasi hasil pengujian model secara berturut-turut adalah 0,$93 ; 0,52 ; 0,44$. Nilai ketepatan atau akurasi prediksi model secara kualitatif pada skala bulanan $100 \%$ dan pada skala harian $52 \%$.
\end{abstract}

Kata Kunci : Prediksi, Curah Hujan, Jaringan Syaraf Tiruan

\section{Latar Belakang}

Cuaca dan iklim merupakan gejala alam yang kompleks dan banyak bergantung dari banyak faktor, baik faktor didalamnya maupun faktor luar seperti topografi suatu wilayah dan posisi lintang dan bujur yang juga ikut andil dalam membentuk iklim suatu wilayah. Pengamatan cuaca yang sudah dilakukan sejak dahulu telah menghasilkan data yang sangat panjang dan merupakan sumber daya yang dapat dianalisa untuk berbagai keperluan, salah satunya adalah untuk terus mencari model prediksi yang semakin hari dituntut untuk semakin akurat. Ide dasar untuk menggunakan jaringan syaraf sebagai metode peramalan didasari pada adanya kesamaan yang ditemukan antara struktur jaringan syaraf dengan pendekatan umum metode peramalan (Halim dan Wibisono, 2000). Berbeda dengan teknik statistik klasik, kelebihan JST sebagai metode peramalan adalah kemampuannya dalam mengenali pola-pola tertentu dengan menggunakan algoritma pembelajaran dan pelatihan selayaknya otak manusia bekerja (Minarti dan Iman, 2011).

Beberapa penelitian yang menggunakan metode JST salah satunya dilakukan oleh Oktaviani dan Afdal (2013) yang mengembangkan JST dengan membandingkan beberapa fungsi pelatihan propagasi balik (backpropagation) dengan memvariasikan jumlah lapisan tersembunyi (hidden layer), jumlah data latih dan jumlah neuron untuk memprediksi curah hujan bulanan di Stasiun Meteorologi Tabing Padang pada jangka waktu 2001-2012. Minarni dan Samiaji (2011) juga mengembangkan JST di Stasiun Meteorologi Bandara Minangkabau dengan skala prediksi yang lebih kecil yakni skala hujan harian dengan memanfaatkan data Total Indeks, air mampu curah dan data konvergensi angin sebagai prediktor.

Pada penelitian ini telah dibangun model JST propagasi balik, dengan data masukan adalah data parameter cuaca seperti suhu udara, kelembaban udara, tekanan udara dan penguapan dan outputnya ada prediksi curah hujan. Model dibangun pada 3 skala waktu yakni skala bulanan, skala dasarian dan skala harian dengan konfigurasi yang berbedabeda pada setiap skala waktu untuk memaksimalkan kemampuan model. Metode ini mengadopsi jaringan syaraf biologis, dimana syaraf menerima impuls dan diproses sedemikian rupa sehingga menghasikan output sebagai hasil dari pemrosesannya. 


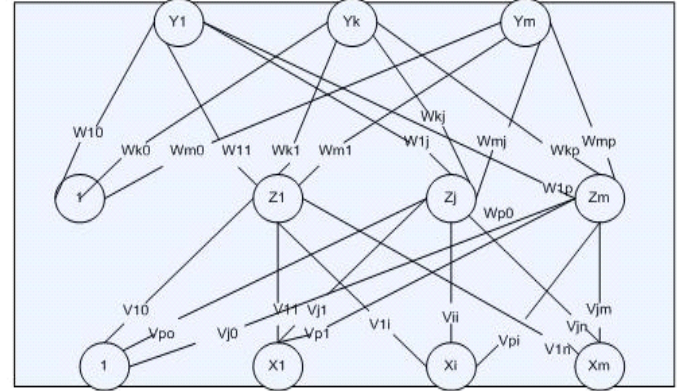

Gambar1. Arsitektur JST (Siang, 2004)

\section{Metodologi}

JST adalah sistem pemrosesan informasi yang memiliki karakteristik mirip dengan jaringan syaraf biologi. Secara umum arsitektur JST terdiri dari masukan (input layer), lapisan tersembunyi (hidden layer) dan keluaran (output) (Agustin, 2012).

JST ditentukan oleh 3 hal :

a. Pola hubungan antar neuron (disebut arsitektur jaringan)

b. Metode untuk menentukan bobot penghubung (disebut metode training/ learning/algoritma)

c. Fungsi aktivasi.

Berikut adalah diagram alir dari seluruh langkah-langkah yang dilakukan dalam penelitian :

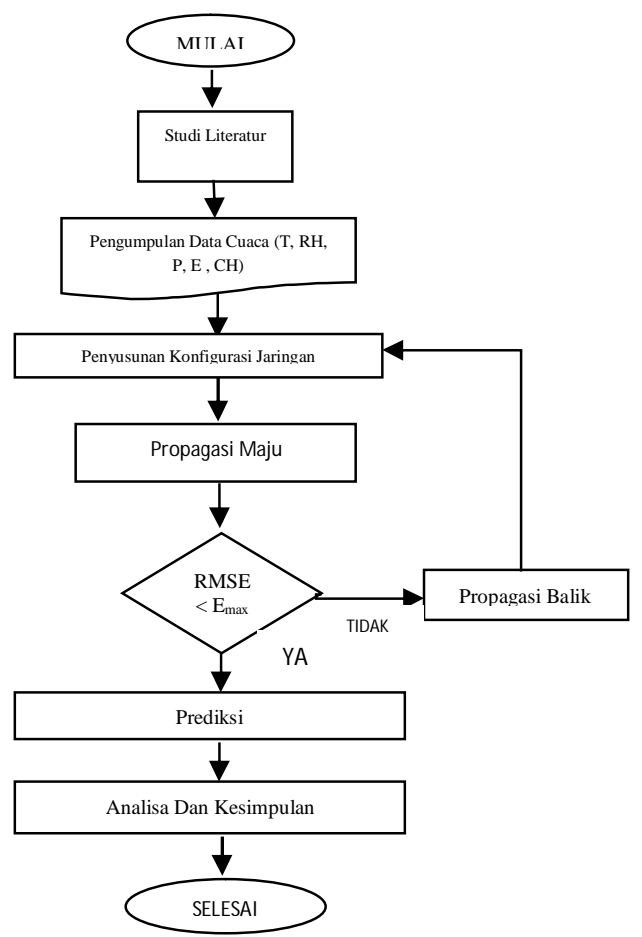

Gambar1. Diagram alir penelitian

\section{Hasil Dan Pembahasan}

Analisis hasil model dibagi menjadi tiga skala yakni skala bulanan, dasarian dan harian. Hal ini dilakukan untuk mengetahui sejauh mana efektifitas dari JST propagasi balik yang dibangun pada data yang sama namun memiliki variasi data pada tingkat yang berbeda.

\subsection{Penerapan Jaringan Syaraf Tiruan Pada Skala Bulanan}

Jaringan syaraf yang dibangun terdiri atas 4 lapisan input, dengan 4 lapisan tersembunyi, dan 1 lapisan output. Lapisan tersembunyi pertama terdiri dari 30 neuron dengan fungsi aktivasi Hyperbolic Tangen Sigmoid. Lapisan tersembunyi ke-2 terdiri dari 20 neuron dengan fungsi aktivasi Log Sigmoid. Lapisan tersembunyi ke-3 terdiri dari 10 neuron dengan fungsi aktivasi Hyperbolic Tangen Sigmoid. Lapisan tersembunyi ke-4 terdiri dari 1 neuron dengan fungsi aktivasi linier. Dan jenis pelatihan yang digunakan adalah Gradient descent with momentum and adaptive learning rate backpropagation. Kemudian ditentukan nilai error maksimalnya adalah 0,1 dan pada prosesnya diperoleh nilai error 0,09 . Pada skala bulanan diperoleh nilai koefisien korelasi tahap pelatihan 0,95; nilai ini menunjukkan bahwa jaringan mampu mengikuti pola data-data masukan yang diberikan dengan baik meskipun tidak sempurna. 


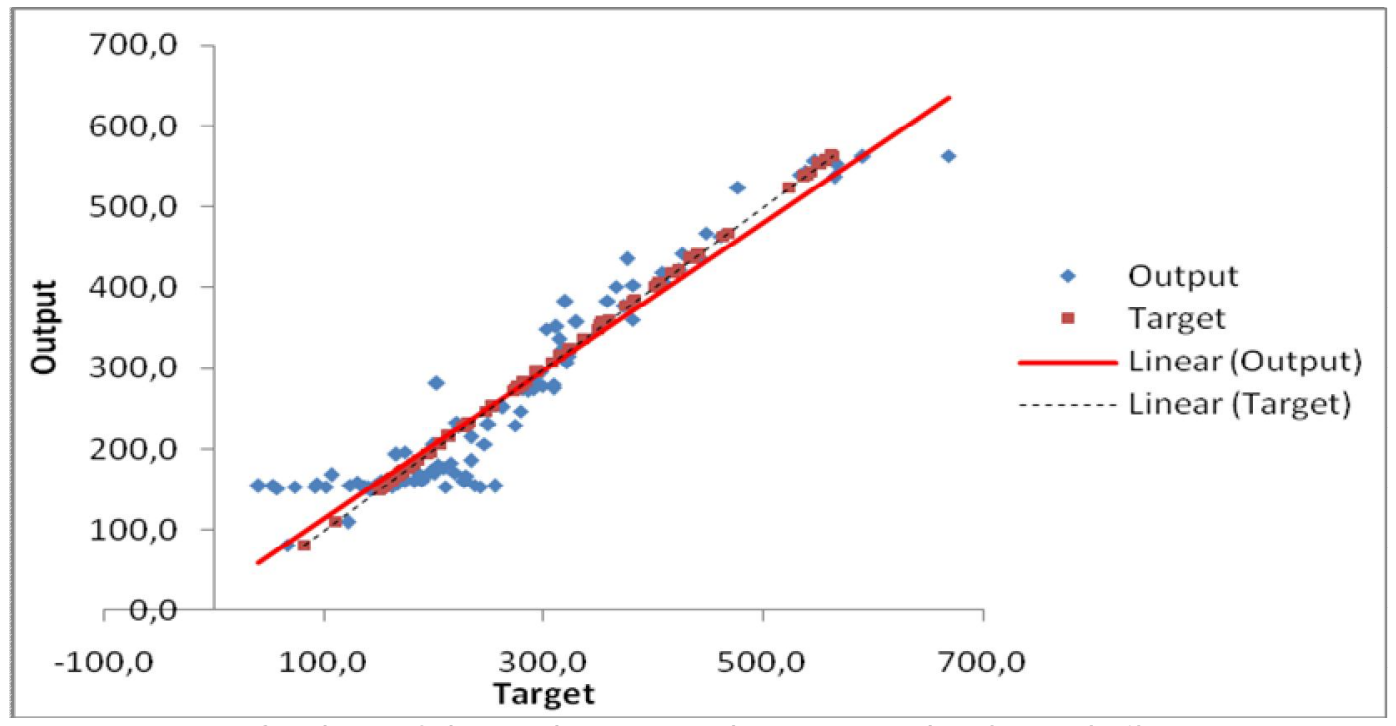

Gambar 2. Sebaran data output dan target pada tahap pelatihan

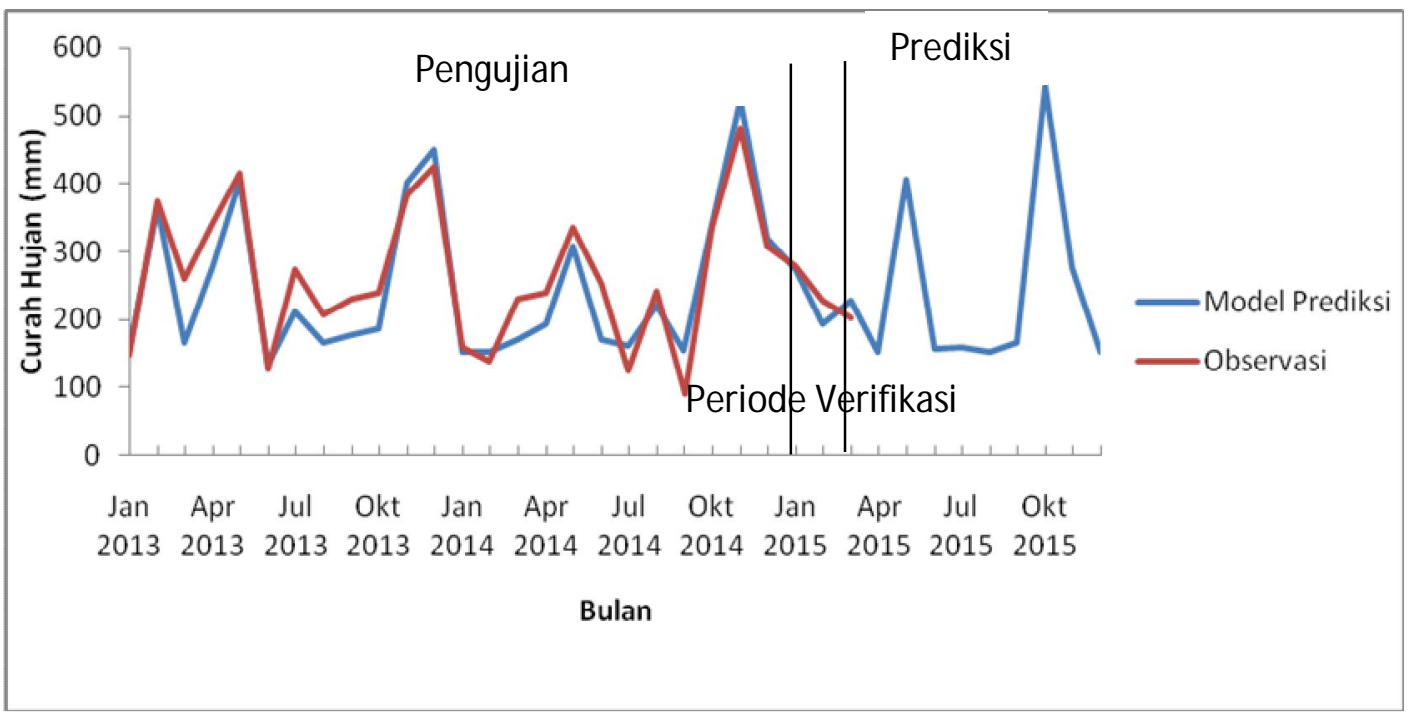

Gambar 3. Curah hujan bulanan model prediksi dan observasi

(Januari 2013-Desember 2015)

Pada Gambar 3. digambarkan tiga tahapan, yang pertama ada tahap pengujian, dimana pada periode ini digunakan 24 data yakni data Januari 2013-Desember 2014. Pada tahap pengujian diperoleh nilai koefisien korelasi 0,93 lebih kecil daripada nilai koefisien korelasi pelatihan, tapi masih dalam kategori tinggi. Kemampuan JST di dalam pengujian disajikan pada periode Verifikasi, dimana pada Bulan Januari 2015 Maret 2015 menunjukkan pola yang dihasilkan output jaringan mampu mengikuti pola target yang diberikan.

Dari hasil verifikasi curah hujan bulanan tahun 2015, dapat diketahui bahwa pada tiga bulan pertama Januari, Februari dan Maret 2015 menunjukan pola yang sama serta nilai curah hujan prediksi yang mendekati nilai hasil observasi. Verifikasi pada tahap ini baru bisa dilakukan untuk 3 bulan yang telah berlalu, yakni Januari, Februari dan Maret, seperti yang terlihat pada tabel 1 :

Tabel 1. Verifikasi prediksi curah hujan model dengan hasil observasi

\begin{tabular}{ccccc}
\hline $\begin{array}{c}\text { Bulan } \\
\text { Ke- }\end{array}$ & Pred. & Kategori & Obs. & Kategori \\
\hline $\mathbf{1}$ & 273,8 & Menengah & 278,4 & Menengah \\
$\mathbf{2}$ & 193,5 & Menengah & 228,0 & Menengah \\
$\mathbf{3}$ & 228,0 & Menengah & 204,6 & Menengah \\
\hline
\end{tabular}

Dari hasil verifikasi diperoleh nilai akurasi kualitatif sebesar $100 \%$. 
Diprediksi bahwa pada tahun 2015 puncak curah hujan terjadi pada bulan Mei dan bulan Oktober, sedangkan bulan bulan dengan curah hujan terendah terjadi pada bulan April, Agustus dan Desember.

\subsection{Penerapan Jaringan Syaraf Tiruan Pada Skala Dasarian}

Jaringan syaraf yang dibangun terdiri atas 4 data input, dengan 6 lapisan tersembunyi, dan 1 lapisan output. Lapisan tersembunyi pertama terdiri dari 25 neuron dengan fungsi aktivasi Hyperbolic Tangen Sigmoid . Lapisan tersembunyi ke-2 terdiri dari 20 neuron dengan fungsi aktivasi Log Sigmoid. Lapisan tersembunyi ke-3 terdiri dari 15 neuron dengan fungsi aktivasi Hyperbolic Tangen Sigmoid. Lapisan tersembunyi keempat terdiri dari 10 neuron dengan fungsi aktivasi Hyperbolic Tangen Sigmoid. Lapisan tersembunyi ke-5 terdiri dari 5 neuron dengan fungsi aktivasi Log Sigmoid. Lapisan tersembunyi ke-6 5 neuron dengan fungsi aktivasi Linier. Jenis pelatihan yang digunakan Gradient descent with momentum and adaptive learning rate backpropagation. Nilai error maksimal yang ditentukan adalah 0,4; dan diperoleh nilai koefisien korelasi tahap pelatihan sebesar 0,77 .

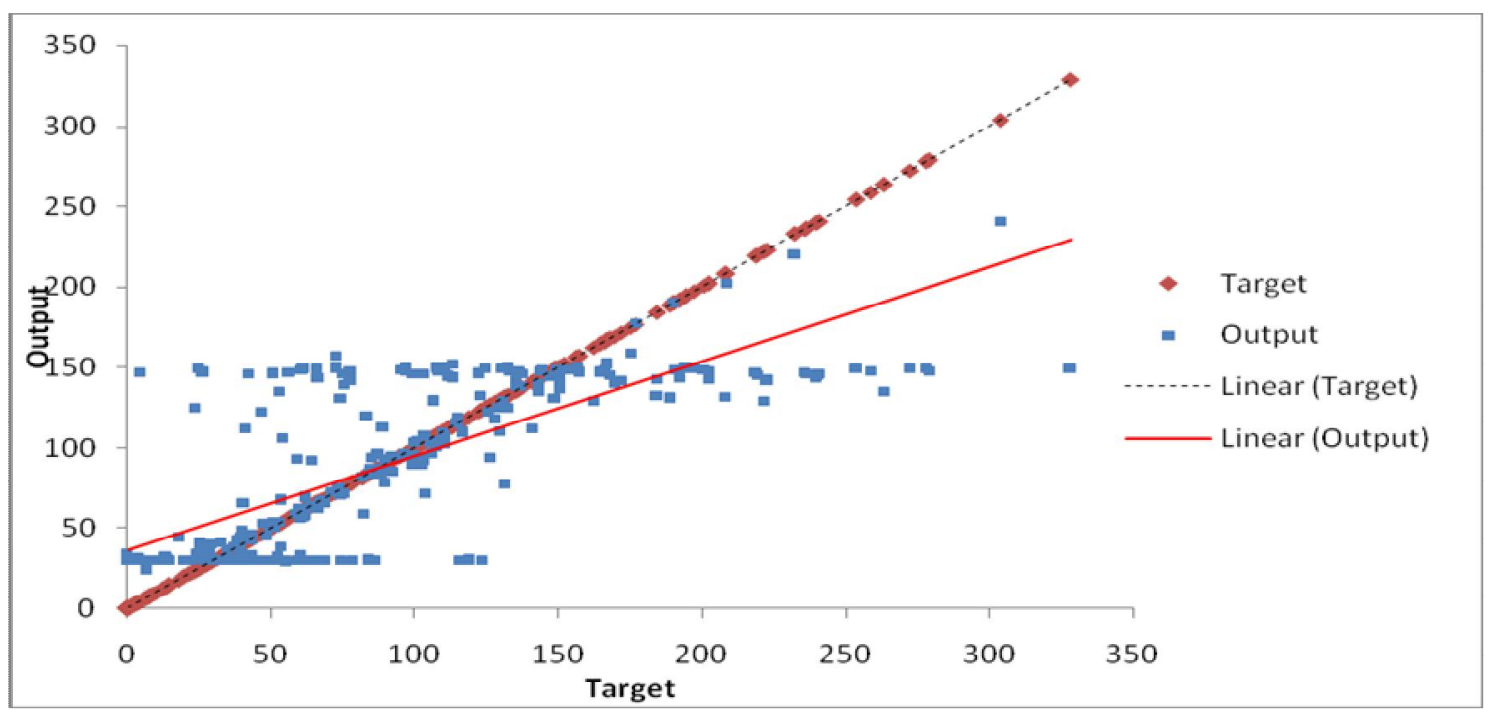

Gambar 4. Sebaran data output dan target pada tahap pelatihan

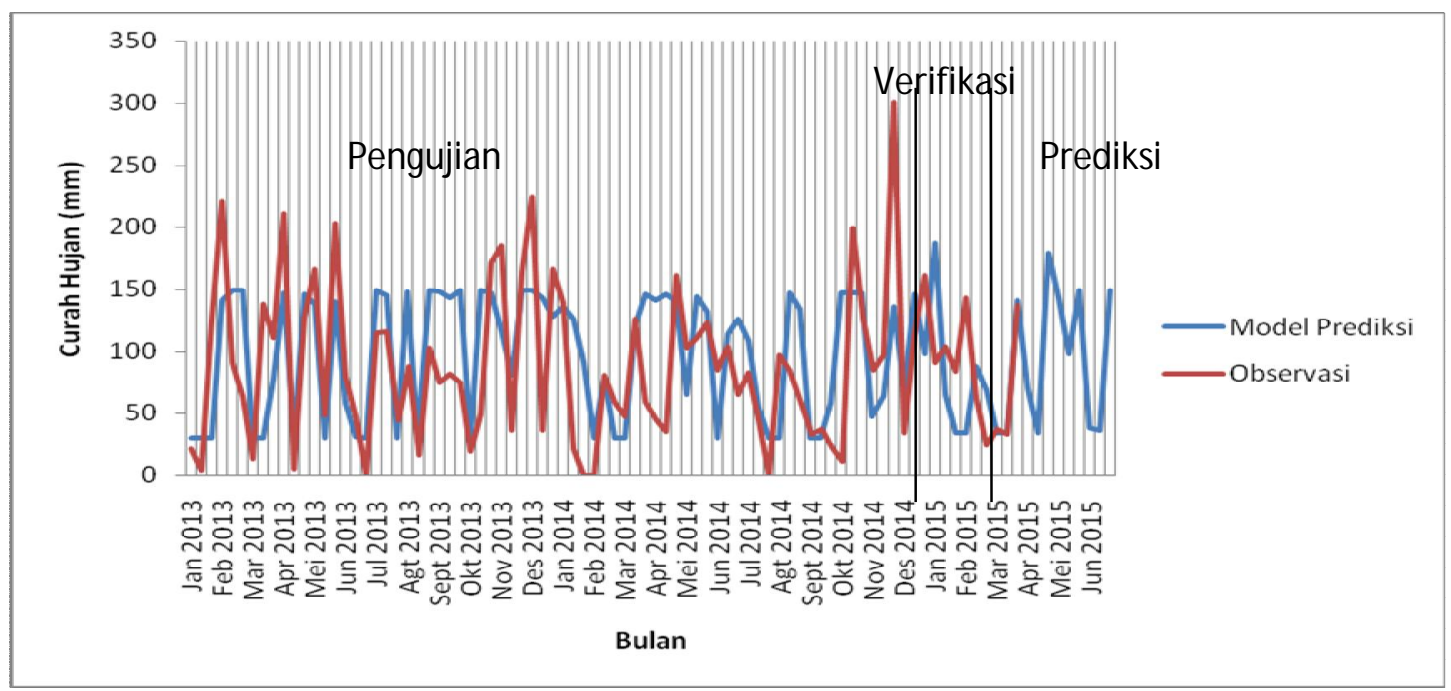

Gambar 5. Curah hujan dasarian model prediksi dan observasi (Januari 2013-Juni2015) 
Pada tahap pengujian digunakan 72 data yakni data dasarian pada Januari 2013Desember 2014. Pada tahap pengujian diperoleh nilai koefisien korelasi 0,52 atau masih dalam kategori kuat. Pada Gambar 5. tergambar bahwa nilai maksimum dari curah hujan yang dapat diikuti oleh JST pada tahap pengujian hanya $150 \mathrm{~mm}$. Untuk kejadian kejadian hujan yang cukup ekstrim yakni diatas $200 \mathrm{~mm}$ belum dapat diikuti dengan baik oleh model.

Verifikasi pada tahap ini baru bisa dilakukan untuk 3 bulan yang telah berlalu, yakni Januari, Februari dan Maret, yakni :

Tabel 2. Verifikasi prediksi curah hujan model dengan hasil observasi

\begin{tabular}{ccc}
\hline Dasarian Ke- & Prediksi & Observasi \\
\hline $\mathbf{1}$ & 187 & 91 \\
$\mathbf{2}$ & 65 & 104 \\
$\mathbf{3}$ & 34 & 84 \\
$\mathbf{4}$ & 34 & 143 \\
$\mathbf{5}$ & 88 & 62 \\
$\mathbf{6}$ & 69 & 24 \\
$\mathbf{7}$ & 34 & 37 \\
$\mathbf{8}$ & 34 & 33 \\
$\mathbf{9}$ & 141 & 137 \\
\hline
\end{tabular}

Karena belum ada standar kategori untuk curah hujan dasarian maka belum dapat diperhitungan akurasi secara kualitatifnya.

\subsection{Penerapan Jaringan Syaraf Tiruan Pada Skala Harian}

Jaringan syaraf yang dibangun terdiri atas 4 data masukan, dengan 8 lapisan tersembunyi, dan 1 lapisan output. Lapisan tersembunyi pertama terdiri dari 35 neuron dengan fungsi aktivasi hyperbolic tangen sigmoid, lapisan tersembunyi ke-2 terdiri dari 30 neuron dengan fungsi aktivasi hyperbolic tangen sigmoid, lapisan tersembunyi ke-3 terdiri dari 25 neuron dengan fungsi aktivasi log sigmoid, lapisan tersembunyi ke-4 terdiri dari 20 neuron dengan fungsi aktivasi hyperbolic tangen sigmoid, lapisan tersembunyi ke-5 terdiri dari 15 neuron dengan fungsi aktivasi hyperbolic tangen sigmoid, lapisan tersembunyi ke-6 terdiri dari 10 neuron dengan fungsi aktivasi hyperbolic tangen sigmoid, lapisan tersembunyi ke-7 terdiri dari 5 neuron dengan fungsi aktivasi log sigmoid, lapisan tersembunyi ke-8 terdiri dari 1 neuron dengan fungsi aktivasi Linier, dan jenis pelatihan yang digunakan adalah gradient descent with momentum and adaptive learning rate backpropagation. Kemudian ditentukan nilai error maksimalnya adalah 0,4 . Pada skala harian diperoleh nilai koefisien korelasi tahap pelatihan 0,78.

Data pengujian pada skala harian ditampilkakan pada gambar 7. Tahap pengujian data dilakukan untuk menguji apakah jaringan mampu mengenali pola data pelatihan dari input data yang diberikan, jika nilai error maksimal sudah mencapai target maka output yang dihasilkan dapat digunakan sebagai data estimasi. Pada tahap pengujian digunakan 730 data yakni data Januari 2013 - Desember 2014. Pada tahap pengujian hanya diperoleh nilai koefisien korelasi 0.44 .

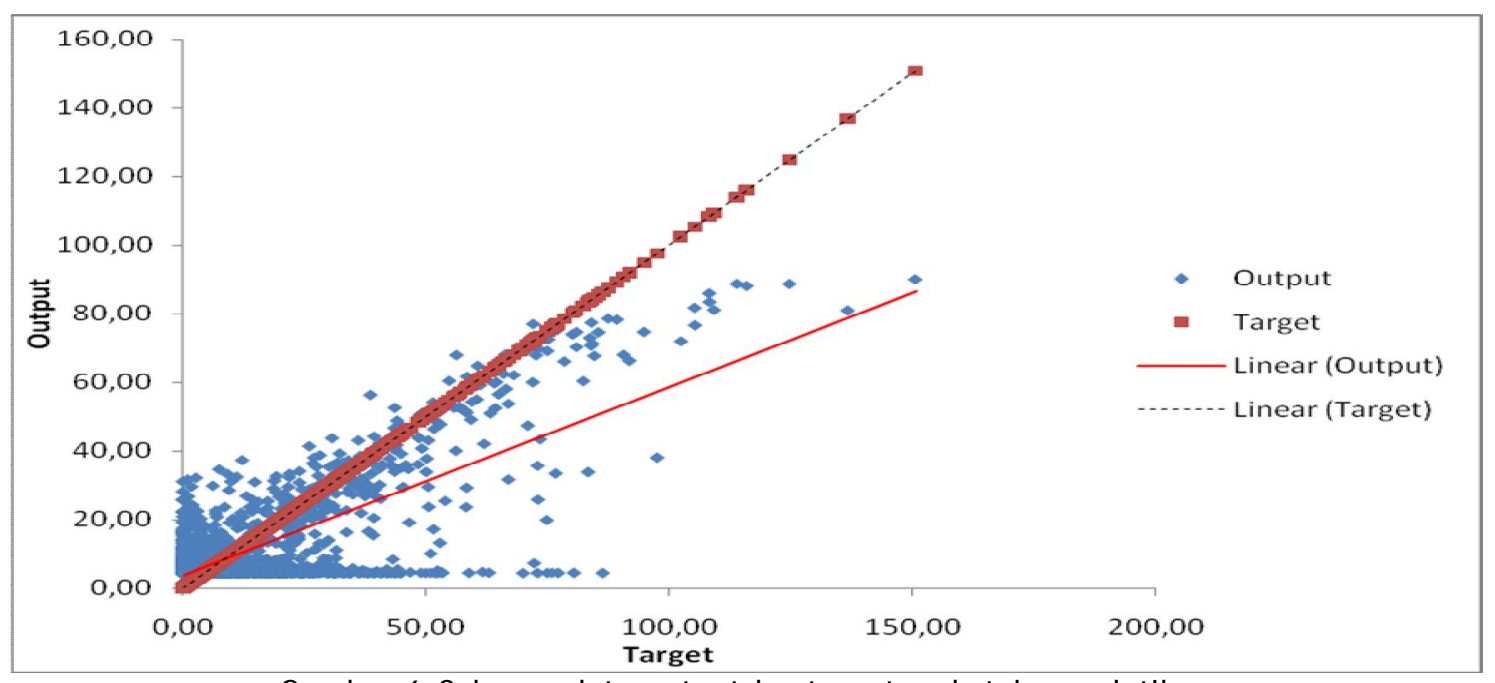

Gambar 6. Sebaran data output dan target pada tahap pelatihan 
Data pengujian pada skala harian ditampilkakan pada gambar 7. Tahap pengujian data dilakukan untuk menguji apakah jaringan mampu mengenali pola data pelatihan dari input data yang diberikan, jika nilai error maksimal sudah mencapai target maka output yang dihasilkan dapat digunakan sebagai data estimasi. Pada tahap pengujian digunakan 730 data yakni data Januari 2013 - Desember 2014. Pada tahap pengujian hanya diperoleh nilai koefisien korelasi 0.44 .
Berdasarkan verifikasi model prakiraan curah hujan pada skala harian diperoleh nilai akurasi prediksi secara kualitatif sebesar 52 $\%$. Terlihat pada grafik nilai curah hujan yang lebih kecil dari $5 \mathrm{~mm}$ masih tidak bisa diprediksi dengan baik, demikian pula dengan kejadian-kejadian hujan sedang masih sulit diprediksi dengan baik oleh model. Untuk verifikasi prakiraan curah hujan pada periode Januari - Maret 2015 ditampilkan pada gambar 8 .

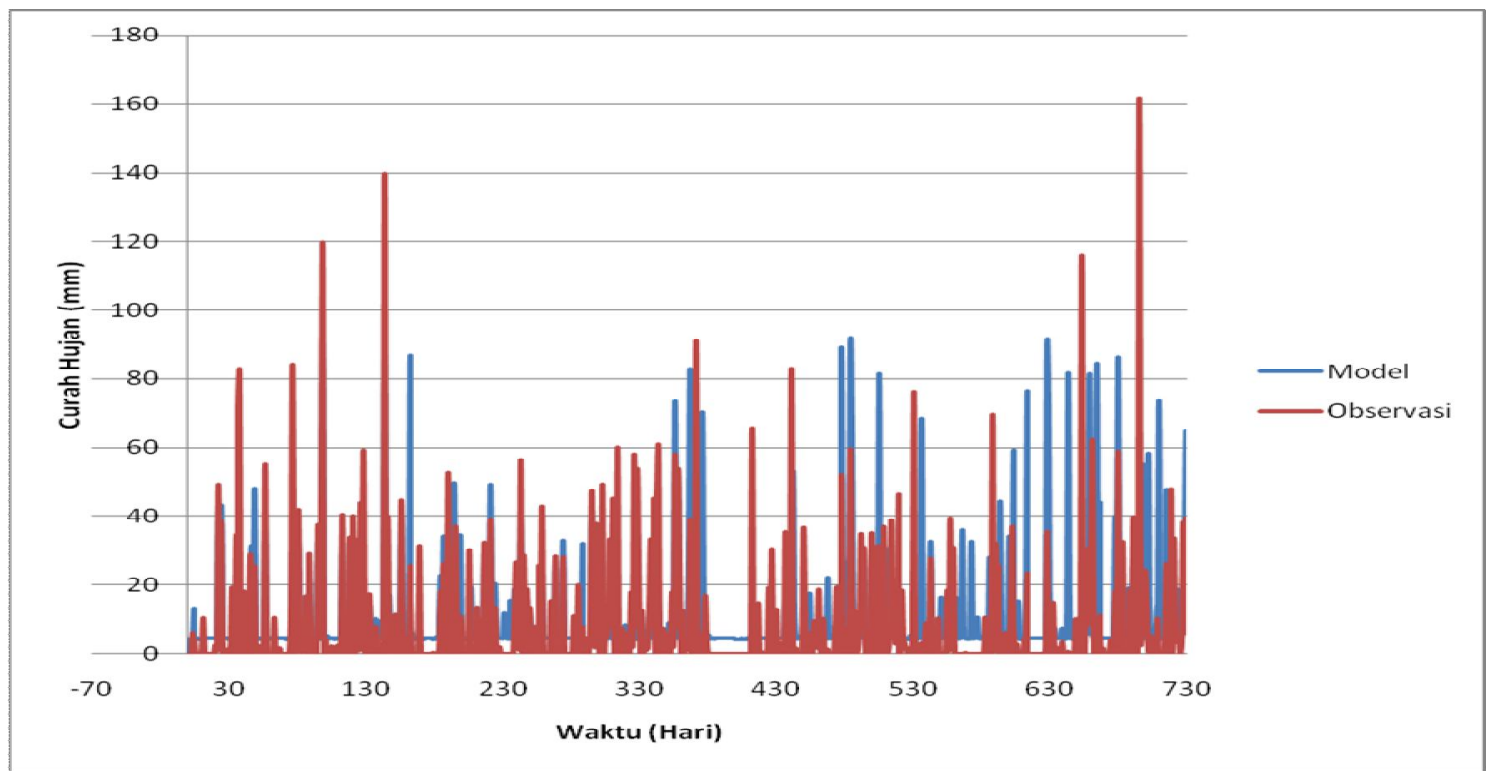

Gambar 7. Data uji model prakiraan curah hujan pada skala harian (Januari 2013 - Desember 2014)

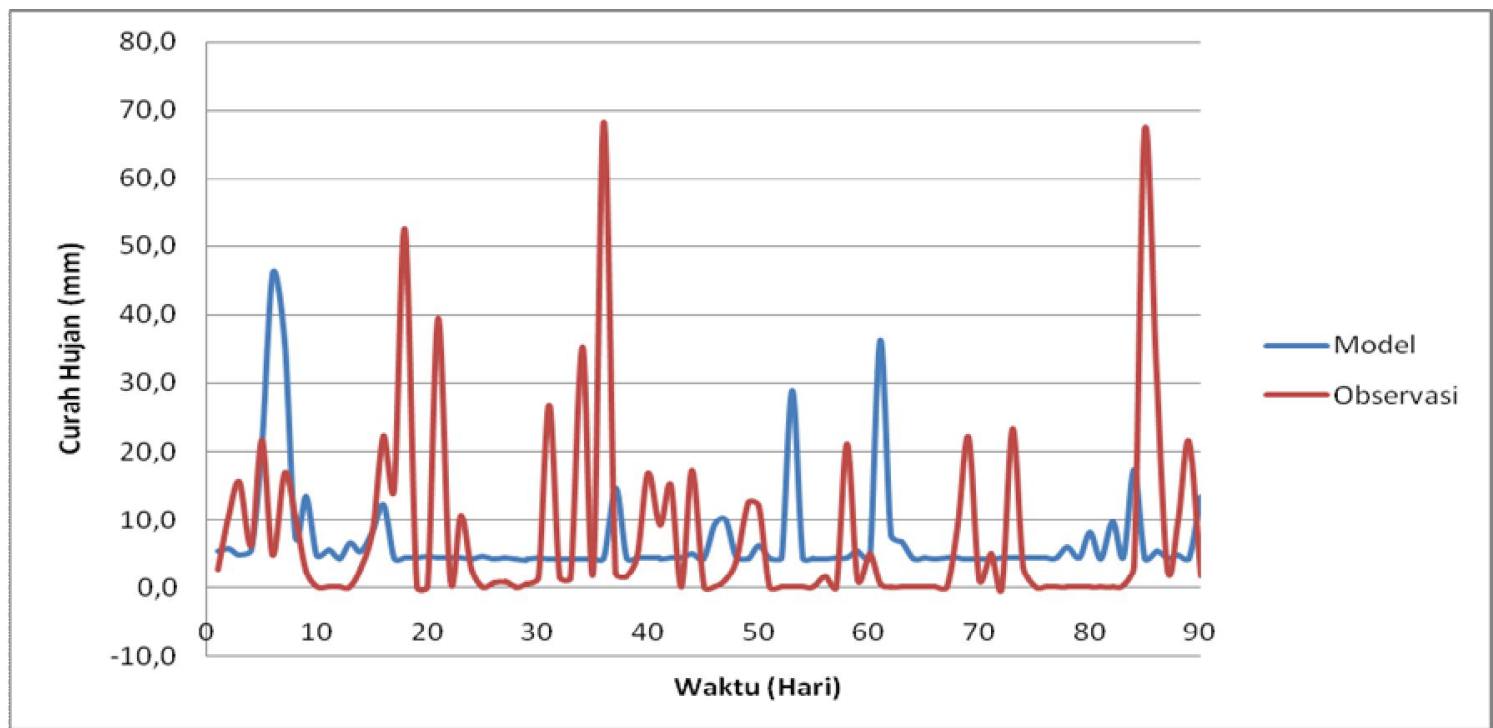

Gambar 8. Verifikasi model prediksi curah hujan harian dengan observasi

(Januari 2015-Maret 2015) 


\subsection{Perbandingan Hasil Pada Skala Waktu Yang Berbeda}

Sebelum membandingkan hasil dari masing-masing kinerja JST pada penerapannya untuk prediksi curah hujan pada berbagai skala, terlebih dahulu akan dibandingkan desain dari JST yang dibangun pada masing-masing skala, sebagai berikut :

Tabel 3. Spesifikasi desain JST pada tiap skala waktu

\begin{tabular}{|c|c|c|c|c|}
\hline No & Spesifikasi & $\begin{array}{c}\text { Skala } \\
\text { Bulanan }\end{array}$ & $\begin{array}{c}\text { Skala } \\
\text { Dasarian }\end{array}$ & $\begin{array}{c}\text { Skala } \\
\text { Harian }\end{array}$ \\
\hline 1. & $\begin{array}{l}\text { Lapisan } \\
\text { tersembunyi }\end{array}$ & 4 lapisan & 6 lapisan & $\begin{array}{c}8 \\
\text { lapisan }\end{array}$ \\
\hline 2. & $\begin{array}{l}\text { Error } \\
\text { Maks. }\end{array}$ & 0,1 & 0,4 & 0,4 \\
\hline 3. & $\begin{array}{l}\text { Fungsi } \\
\text { Pelatihan }\end{array}$ & \multicolumn{3}{|c|}{$\begin{array}{l}\text { fungsi pelatihan yang menga- } \\
\text { update nilai bobot dan bias sesuai } \\
\text { dengan penurunan gradien } \\
\text { momentum dan tingkat pelatihan } \\
\text { yang adaptif. }\end{array}$} \\
\hline
\end{tabular}

Desain jaringan yang dibangun memiliki spesifikasi yang berbeda untuk masingmasing skala. Hal ini diperlukan karena adanya tingkat fluktuasi data yang berbedabeda untuk masing-masing skala. Skala yang pertama kali diteliti adalah skala bulanan karena memiliki fluktuasi data yang lebih kecil dibanding skala lainnya maka JST dengan mudah dapat menemukan polanya dengan baik meski ditetapkan nilai error maksimum yang sangat kecil yakni 0,1 . Untuk skala dasarian memiliki sifat data yang lebih acak dari pada skala bulanan sehingga jika disamakan desainnya dengan skala bulanan maka hasil koefisien korelasinya akan sangat rendah, sehingga kemudian dilakukan kembali penyesuaian desain JST untuk meningkatkan kinerjanya. Demikian pula dengan data pada skala harian. Data ini memiliki tingkat keacakan yang sangat besar dibanding skala lainnya. Dengan menggunakan 6 lapisan tersembunyi sulit ditemukan nilai koefisien korelasi yang lebih dari 0,2. Penyesuaian dilakukan dengan menambah lapisan tersembunyi menjadi 8 lapisan tersembunyi, meskipun hal ini beresiko memperlambat kinerja desain namun tetap saja sulit untuk memperoleh nilai koefisien korelasi yang tinggi sehingga hanya diperoleh nilai koefisien korelasi uji sebesar 0,44.

Pada tabel 4. Disajikan perbandingan dari hasil penilitian yang telah dilakukan pada masing-masing skala waktu :
Tabel 4. Perbandingan hasil dari masingmasing skala waktu

\begin{tabular}{llccc}
\hline No & \multicolumn{1}{c}{ Ket. } & $\begin{array}{c}\text { Skala } \\
\text { Bulanan }\end{array}$ & $\begin{array}{c}\text { Skala } \\
\text { Dasarian }\end{array}$ & $\begin{array}{c}\text { Skala } \\
\text { Harian }\end{array}$ \\
\hline 1. & $\begin{array}{l}\text { Error yang } \\
\text { dicapai }\end{array}$ & 0,09 & 0,4 & 0,4 \\
2. & $\begin{array}{l}\text { Koefisien } \\
\text { korelasi } \\
\text { pelatihan } \\
\text { Koefisien } \\
\text { korelasi } \\
\text { pengujian }\end{array}$ & 0,95 & 0,77 & 0,78 \\
4. & $\begin{array}{l}\text { Produk } \\
\text { prediksi } \\
\text { Akurasi } \\
\text { kualitatf }\end{array}$ & 12 bulan & 6 bulan & 90 hari \\
5. & 100 & -52 & 0,44 \\
\hline
\end{tabular}

\section{Kesimpulan}

Metode JST yang telah dibuat untuk memprediksi curah hujan pada skala bulanan,dasarian dan harian memberi hasil yang berbeda untuk masing-masing skala. Skala bulanan dikenali dengan lebih baik oleh JST dibanding skala dasarian dan harian, dengan nilai koefisien koefisien korelasi pelatihan secara berturut-turut adalah 0,95; 0,77 dan 0,78. Dan untuk koefisien korelasi pada proses pengujian pada skala bulanan, dasarian dan harian secara berturut-turut adalah 0,$93 ; 0,52$ dan 0,44 dengan nilai error pada masing-masing skala adalah 0,$1 ; 0,4$ dan 0,4. Nilai koefisien korelasi tersebut selaras dengan tingkat akurasi prediksi secara kualitatifnya yakni 100\% untuk prediksi hujan bulanan dan $52 \%$ pada prediksi hujan harian.

\section{Daftar Pustaka}

Agustin, M. 2012. Penggunaan Jaringan Syaraf Tiruan Propagasi Balik Dalam Penerimaan Mahasiswa Baru Pada Jurusan Teknik Komputer Di Politeknik Negeri Sriwijaya.Skripsi. Tidak dipublikasikan. Semarang: Universitas Diponegoro.

Halim, S. dan Wibisono, A.M., 2000, Penerapan Jaringan Syaraf Tiruan untuk Peramalan, Jurnal Teknik Industri, Vo1.2, No.2.

Minarni dan Samiaji, B.I., 2011. Prediksi Terjadinya Hujan Harian dengan Metode Jaringan Syaraf Tiruan di Stasiun Meteorologi Bandara Minangkabau. Jurnal Poli Rekayasa Vol.6, No.2, Jurusan Teknik Informatika Institut Teknologi Padang: 129:138. 
Minarti dan Iman, S.B., 2011, Prediksi Terjadinya Hujan Harian dengan Metode Jaringan Syaraf Tiruan di Stasiun Meteorologi Bandara Minangkabau, Jurnal Poli Rekayasa Vol.6, No.2, Jurusan Teknik Informatika Institut Teknologi Padang.

Oktaviani, C. dan Afdal. 2013. Prediksi Curah Hujan Bulanan Menggunakan Jaringan Syaraf Tiruan Dengan Beberapa Fungsi Pelatihan Backpropagation. Jurnal Fisika Universitas Andalas Vol.2 No.4, Oktober 2013:228 - 237.

Siang, J.J., 2004. Jaringan Syaraf Tiruan Dan Pemrogramannya Menggunakan Matlab Dan Excel Link. Yogyakarta : Graha Ilmu. 